\title{
INTEGRATION OF THE FUZZY FAILURE MODE AND EFFECT ANALYSIS (FUZZY FMEA) AND THE ANALYTICAL NETWORK PROCESS (ANP) IN MARKETING RISK ANALYSIS AND MITIGATION
}

\author{
Nuria Rahmatin ${ }^{1}$, Imam Santoso ${ }^{1 *}$, Christina Indriani ${ }^{1}$, Sutik Rahayu ${ }^{1}$, Shinta Widyaningtyas ${ }^{1}$ \\ ${ }^{1}$ Department of Agro-industrial Technology, Universitas Brawijaya, Jalan Veteran, Ketawanggede, \\ Lowokwaru, Malang City 56145, East Java, Indonesia
}

(Received: March 2017 / Revised: February 2018 / Accepted: May 2018)

\begin{abstract}
Marketing plays an important role in determining an enterprise's success. Inappropriate marketing strategy can lead to various risks, especially for SMEs that have not prepared their risk management. This research aims to identify and specify marketing strategy priorities in the production of potato chips, and to decide anticipationary action in determining risk mitigation. The research is a case study of XYZ company. The method used for risk analysis was Fuzzy FMEA, and that used to specify the strategic priorities was ANP. The results indicate that the most potential risks in potato chip marketing are promotion risk, which is caused by inappropriate steps with regard to promotion targets, and the absence of a brand image. The primary strategy in market risk mitigation is to improve sub-strategy promotion, which increases the effectiveness of promotion facilities and infrastructure, complies with the development of information and communication media, and maintains service quality in the sub-criteria of building and maintaining good relations with customers.
\end{abstract}

Keywords: ANP; Fuzzy FMEA; Marketing risk; Risk mitigation

\section{INTRODUCTION}

The Indonesian economy has developed rapidly in several sectors, especially in agroindustry. One of the contributing factors to this development has been Small and Medium Enterprises (SMEs). According to Wang (2016), SMEs play a part in economic development, as the employment providers in developing countries. One of their roles is to increase national foreign exchange in the export market (Berry et al., 2001).

Marketing is regarded as the primary factor in product survivability in the market (Vorhies et al., 2009). Its effectiveness can be seen from the possibilities of expansion, owner prosperity, and good business prospects; as stated by Kumar (2012), marketing is the main part of business success.

However, inappropriate marketing strategy can lead to risks for SMEs. Strategy and operational marketing are the accumulation of a company's capability of coordinating its strategic marketing activity (Krasnikov \& Jayachandran, 2008). Customers' taste is considered as a black box, which is hard to figure out and is regarded as the source of uncertain demand towards their products (Solomon, 2006). Risks come from uncertainty (Eiser et al., 2012). Uncertain demand may also be caused by market uncertainty, which leads to various marketing risks.

\footnotetext{
*Corresponding author's email: imamsantoso@ub.ac.id, Tel. +62-81334408203, Fax.+62-341-568917 Permalink/DOI: https://doi.org/10.14716/ijtech.v9i4.2197
} 
Risk management is defined as a process of identifying and assessing risk in order to minimize it to an acceptable level (Tohidi, 2011; Serpella et al., 2014). Risk management can help SME owners to identify significant risks that threaten their business (Falkner \& Hiebl, 2014; Brustbauer, 2016).

Failure Mode and Effect Analysis (FMEA) was first developed to analyze systematic failure and the impact of product survivability, especially in the aviation sector (Bowles \& Peláez, 1995). The main advantage of FMEA is its ability to identify critical points in order to help make corrective or preventative decisions (Segismundo \& Miguel, 2008; Parsana \& Patel, 2014; Cameron et al., 2017). Fuzzy FMEA is the developed version of conventional FMEA and has been implemented in several researches, such as those of Dagsuyu et al. (2016) and Silva et al. (2014).

Kumru and Kumru (2013) state that Fuzzy FMEA can be implemented to overcome the limitations of conventional FMEA, such as subjective and qualitative description, interest rate risk, and the difference in risk representation. There are several methods used to assess risk, such as the Monte Carlo method (Chaudary \& Mohamed, 2017), fuzzy logic (Petrovic et al., 2014), and the Analytical Hierarchy Process (Aminbakhsh et al., 2013; Santoso et al., 2017). The Analytical Network Process (ANP) is the general form of AHP (Saaty, 1996). It is used to describe problems hierarchically, a process in which every element is considered independently, which was why ANP was developed to improve AHP (Saaty, 1996). Many studies have shown that the implementation of ANP leads to better results. The purpose of this research is to identify and assess potato chip marketing risks by using Fuzzy FMEA and ANP.

\section{METHODOLOGY}

The research comprises a case study conducted on the XYZ SME in Batu, Indonesia, which produces potato chips. The marketing risk variables were determined by considering previous research that has been verified in the field; these can be seen in Table 1. After the identification process, the next step was to specify the cause and effect of the risks (Table 2), which were identified by using Fuzzy FMEA (Table 3).

The Fuzzy FMEA procedure was adopted from Wang et al. (2009). The primary strategy in market risk mitigation was specified using the ANP method, a developed version of AHP which is able to make decision based on several complex criteria. The procedure of the ANP method was adopted from Saaty (1996).

Table 1 Market risk variables in potato chip marketing

\begin{tabular}{|c|c|c|}
\hline Risk Variable & Indicator & Author \\
\hline \multirow{3}{*}{ External } & IDR rate & $\begin{array}{l}\text { Kang \& Feng (2009); Ghandi \& Lawell (2017); } \\
\text { Dhanani (2008) }\end{array}$ \\
\hline & Price fluctuation & $\begin{array}{l}\text { Dewi et al. (2015); Suryaningrat (2016); Weron, } \\
(2000) \text {; He et al. (2012); Henriques \& Sadorsky } \\
(2010) \text {; Nie et al. (2016) }\end{array}$ \\
\hline & Competitiveness & $\begin{array}{l}\text { Cibinskienea \& Snieskiene (2015); Rochman et al., } \\
\text { (2011); Anggadwita et al. (2016) }\end{array}$ \\
\hline \multirow{4}{*}{ Internal } & $\begin{array}{l}\text { Marketing } \\
\text { strategy }\end{array}$ & $\begin{array}{l}\text { Aghazadeh (2015); Hasan \& Ali, (2015); Ryals and } \\
\text { Knox (2005) }\end{array}$ \\
\hline & Product & Astuti et al. (2015); Rider et al. (2009) \\
\hline & Distribution & $\begin{array}{l}\text { Abril \& Rodriguez (2016); Dawes \& Nenycz-Thiel } \\
\text { (2013); Yoo et al. (2000) }\end{array}$ \\
\hline & Promotion & $\begin{array}{l}\text { Lowe (2010); Freixanet (2012); Bao \& Chang (2014); } \\
\text { Pauwels et al. (2016); Haddoud et al. (2016) }\end{array}$ \\
\hline
\end{tabular}


Table 2 Details of cause and effect of market risk in potato chip marketing

\begin{tabular}{|c|c|c|c|}
\hline Parameter & Risk & Cause & Effect \\
\hline & Interest increase (R1). & Inflation. & $\begin{array}{l}\text { Price increase of goods and } \\
\text { services. }\end{array}$ \\
\hline Interest rate & $\begin{array}{l}\text { IDR exchange rate } \\
\text { decrease (R2). }\end{array}$ & $\begin{array}{l}\text { Price increase of crude oil } \\
\text { strengthens economic sectors in } \\
\text { superpower countries and } \\
\text { lowers exchange rates in } \\
\text { developing countries. }\end{array}$ & $\begin{array}{l}\text { Purchasing power decreases } \\
\text { for goods and services. }\end{array}$ \\
\hline \multirow[t]{2}{*}{ Price fluctuation } & $\begin{array}{l}\text { Scarcity of raw } \\
\text { materials (R3). }\end{array}$ & $\begin{array}{l}\text { Unpredictable natural } \\
\text { conditions (seasons or weather) } \\
\text { and potato pests cause harvest } \\
\text { failure. }\end{array}$ & $\begin{array}{l}\text { Price increase of raw } \\
\text { materials (potatoes) and } \\
\text { disruption to production } \\
\text { process activities. }\end{array}$ \\
\hline & $\begin{array}{l}\text { Energy cost increase } \\
\text { (R4). }\end{array}$ & $\begin{array}{l}\text { Certain government policies } \\
\text { related to subsidy and tax. }\end{array}$ & $\begin{array}{l}\text { High cost of energy (LPG, } \\
\text { electricity, gasoline, etc.). }\end{array}$ \\
\hline \multirow{3}{*}{ Competitiveness } & $\begin{array}{l}\text { Stiff competition } \\
\text { between similar } \\
\text { products (R5). }\end{array}$ & $\begin{array}{l}\text { Competitors who produce } \\
\text { similar products on a limited } \\
\text { scale (small). }\end{array}$ & $\begin{array}{l}\text { Production capacity } \\
\text { difficulties in developing } \\
\text { and dominating the market. }\end{array}$ \\
\hline & New competitors (R6). & $\begin{array}{l}\text { High demand from market for } \\
\text { potato chip products. }\end{array}$ & Decrease in level of sales. \\
\hline & Substitute goods (R7). & $\begin{array}{l}\text { High price and limited } \\
\text { availability of raw materials. }\end{array}$ & $\begin{array}{l}\text { Decrease in level of sales; } \\
\text { consumers buy substitute } \\
\text { goods which are more } \\
\text { affordable. }\end{array}$ \\
\hline \multirow{2}{*}{$\begin{array}{l}\text { Marketing } \\
\text { strategy }\end{array}$} & $\begin{array}{l}\text { Inappropriate cost } \\
\text { leadership strategy and } \\
\text { services (R8). }\end{array}$ & $\begin{array}{l}\text { Miscalculation of strategy or } \\
\text { price determination focus, and } \\
\text { services. }\end{array}$ & $\begin{array}{l}\text { Consumers feel } \\
\text { disappointed then decide to } \\
\text { stop buying. }\end{array}$ \\
\hline & Poor loyalty (R9). & $\begin{array}{l}\text { Incompetence and company } \\
\text { benefit- oriented. }\end{array}$ & $\begin{array}{l}\text { Customers feel } \\
\text { disrespectful and their } \\
\text { needs are neglected. }\end{array}$ \\
\hline \multirow[t]{2}{*}{ Product } & $\begin{array}{l}\text { Low ability to launch } \\
\text { new goods and services } \\
\text { (R10). }\end{array}$ & $\begin{array}{l}\text { No adequate or continuous } \\
\text { market research and slow } \\
\text { development of new goods and } \\
\text { services. }\end{array}$ & $\begin{array}{l}\text { Goods and services cannot } \\
\text { meet the growing market } \\
\text { demand and trends so } \\
\text { consumers choose } \\
\text { competitors' products. }\end{array}$ \\
\hline & $\begin{array}{l}\text { Decrease in quality of } \\
\text { goods and services } \\
\text { (R11). }\end{array}$ & $\begin{array}{l}\text { No quality standardization or } \\
\text { SOP of production process and } \\
\text { services. }\end{array}$ & $\begin{array}{l}\text { Different quality of goods } \\
\text { and services. }\end{array}$ \\
\hline \multirow[t]{2}{*}{ Distribution } & $\begin{array}{l}\text { Inappropriate } \\
\text { distribution process } \\
\text { (R12). }\end{array}$ & $\begin{array}{l}\text { No special team which is } \\
\text { responsible for product } \\
\text { distribution and limited retailers } \\
\text { who promote the products } \\
\text { (potato chips). }\end{array}$ & $\begin{array}{l}\text { Disruption to product } \\
\text { distribution and limited } \\
\text { marketing areas. }\end{array}$ \\
\hline & $\begin{array}{l}\text { Limited distribution } \\
\text { facilities and } \\
\text { infrastructure (R13). }\end{array}$ & $\begin{array}{l}\text { No computerized } \\
\text { documentation of product } \\
\text { distribution system and no SOP } \\
\text { related to distribution. }\end{array}$ & $\begin{array}{l}\text { Delivery delays and } \\
\text { product damage during } \\
\text { distribution. }\end{array}$ \\
\hline \multirow{3}{*}{ Promotion } & $\begin{array}{l}\text { Ineffective promotion } \\
\text { activities (R14). }\end{array}$ & $\begin{array}{l}\text { No information technology } \\
\text { involvement and limited } \\
\text { promotion budget. }\end{array}$ & $\begin{array}{l}\text { Promotions run slowly and } \\
\text { are not well targeted. }\end{array}$ \\
\hline & $\begin{array}{l}\text { Absence of brand image } \\
\text { (R15). }\end{array}$ & $\begin{array}{l}\text { The company has yet to } \\
\text { strengthen its brand image. }\end{array}$ & $\begin{array}{l}\text { Lack of loyal customers } \\
\text { and promotion is hard to } \\
\text { conduct. }\end{array}$ \\
\hline & $\begin{array}{l}\text { Neglect of promotional } \\
\text { activities (R16). }\end{array}$ & No specific team for marketing. & $\begin{array}{l}\text { Enterprise lacks } \\
\text { competitiveness. }\end{array}$ \\
\hline
\end{tabular}




\section{RESULTS AND DISCUSSION}

\subsection{Assessing the Marketing Risk of Potato Chips}

In order to investigate the market risk of potato chips, quantitative risk assessment (S: Severity; O: Occurence; D: Detection, RPN: Risk Priority Number) was conducted using fuzzy FMEA. The assessment refers to the 16 risk indicators previously identified. Based on the assessment results, three risk indicators have the highest FRPN and need to be managed and solved soon. The risk assessment results on potato chips can be seen in Table 3.

Table 3 Measurement results of marketing risk of potato chips

\begin{tabular}{|c|c|c|c|c|c|c|c|c|}
\hline & Risk & $\mathrm{S}$ & $\mathrm{O}$ & $\mathrm{D}$ & RPN & Rank & $\begin{array}{l}\text { Fuzzy } \\
\text { RPN }\end{array}$ & Rank \\
\hline \multirow{2}{*}{ Interest Rate } & $\begin{array}{l}\text { Interest increase } \\
\text { (R1) }\end{array}$ & 2 & 2 & 9 & 36 & 9 & 2.76 & 10 \\
\hline & $\begin{array}{l}\text { IDR exchange rate } \\
\text { decrease (R2) }\end{array}$ & 2 & 2 & 9 & 36 & 9 & 2.78 & 9 \\
\hline \multirow{2}{*}{$\begin{array}{l}\text { Price } \\
\text { Fluctuation }\end{array}$} & $\begin{array}{l}\text { Scarcity of raw } \\
\text { materials (R3) }\end{array}$ & 3 & 2 & 8 & 48 & 8 & 2.72 & 14 \\
\hline & $\begin{array}{l}\text { Energy cost increase } \\
\text { (R4) }\end{array}$ & 3 & 2 & 8 & 48 & 8 & 2.71 & 15 \\
\hline \multirow{3}{*}{ Competitiveness } & $\begin{array}{l}\text { Stiff competition } \\
\text { between similar } \\
\text { products (R5) }\end{array}$ & 5 & 4 & 8 & 160 & 2 & 4.85 & 2 \\
\hline & $\begin{array}{l}\text { New competitors } \\
\text { (R6) }\end{array}$ & 5 & 3 & 7 & 105 & 5 & 4.1 & 5 \\
\hline & $\begin{array}{l}\text { Substitute goods } \\
\text { (R7) }\end{array}$ & 4 & 3 & 8 & 96 & 6 & 4.19 & 4 \\
\hline \multirow[t]{2}{*}{$\begin{array}{l}\text { Marketing } \\
\text { strategy }\end{array}$} & $\begin{array}{l}\text { Inappropriate cost } \\
\text { leadership strategy } \\
\text { and services } \\
\text { (R8) }\end{array}$ & 3 & 2 & 8 & 48 & 8 & 2.75 & 12 \\
\hline & Poor loyalty (R9) & 3 & 2 & 8 & 48 & 8 & 2.73 & 13 \\
\hline \multirow[t]{2}{*}{ Product } & $\begin{array}{l}\text { Low ability to } \\
\text { launch new goods } \\
\text { and services } \\
\text { (R10) }\end{array}$ & 3 & 4 & 9 & 108 & 4 & 3.91 & 7 \\
\hline & $\begin{array}{l}\text { Decrease in quality } \\
\text { of goods and } \\
\text { services (R11) }\end{array}$ & 8 & 2 & 8 & 128 & 3 & 4.05 & 6 \\
\hline \multirow{2}{*}{ Distribution } & $\begin{array}{l}\text { Inappropriate } \\
\text { distribution process } \\
\text { (R12) }\end{array}$ & 2 & 2 & 9 & 36 & 9 & 2.77 & 11 \\
\hline & $\begin{array}{l}\text { Limited distribution } \\
\text { facilities and } \\
\text { infrastructure (R13) }\end{array}$ & 3 & 3 & 9 & 81 & 7 & 3.39 & 8 \\
\hline \multirow{3}{*}{ Promotion } & $\begin{array}{l}\text { Ineffective } \\
\text { promotion activities } \\
\text { (R14) }\end{array}$ & 5 & 7 & 7 & 245 & 1 & 6.26 & 1 \\
\hline & $\begin{array}{l}\text { Absence of brand } \\
\text { image } \\
(\mathrm{R} 15)\end{array}$ & 5 & 4 & 8 & 160 & 2 & 4.83 & 3 \\
\hline & $\begin{array}{l}\text { Neglect of } \\
\text { promotional } \\
\text { activities (R16) }\end{array}$ & 2 & 2 & 8 & 32 & 10 & 2.64 & 16 \\
\hline
\end{tabular}


Based on Table 3, there is a gap in the RPN score between conventional FMEA and fuzzy FMEA. For the first priority scale, the suggestion for improvement relates to the inappropriateness of the distribution system, with an RPN of 245 and FRPN of 6.26. This FRPN score is used to determine the specific rate because on RPN, the rate of risk subcriterion has a similar score. For example, if the interest rate and exchange rate subcriteria indicate 36 in RPN, the rate will also be similar; that is, 9. Therefore, the RPN is fuzzificated to obtain specific numbers; 2.78 as the exchange rate and 2.76 as the interest rate, ranked 9 and 10 respectively.

Table 3 shows that based on the FRPN there are 7 potential risks. The urgent risks are promotion risk caused by inappropriateness of the promotional activities and its promotion target (R14), and the absence of brand image (R15). The external factor due to competitiveness of the similar production (R5), and the presence of substitute products (R7) and new competitors (R6). The third risk is product risk, which is related to the declining quality of its product and service (R11), and low ability to launch new goods and services (R10). Thus, these risks are the most potential risks. Therefore, a new strategy needs to be assigned in order to solve them all. Strategy of risk mitigation is expected to reduce the risks, or even better to clear them up.

\subsection{Mitigation Risk Strategy}

The findings on risk priority were then used as references for the model strategy of market risk mitigation. Based on the previous analysis, the correlation between each criterion can be used to create this model strategy.

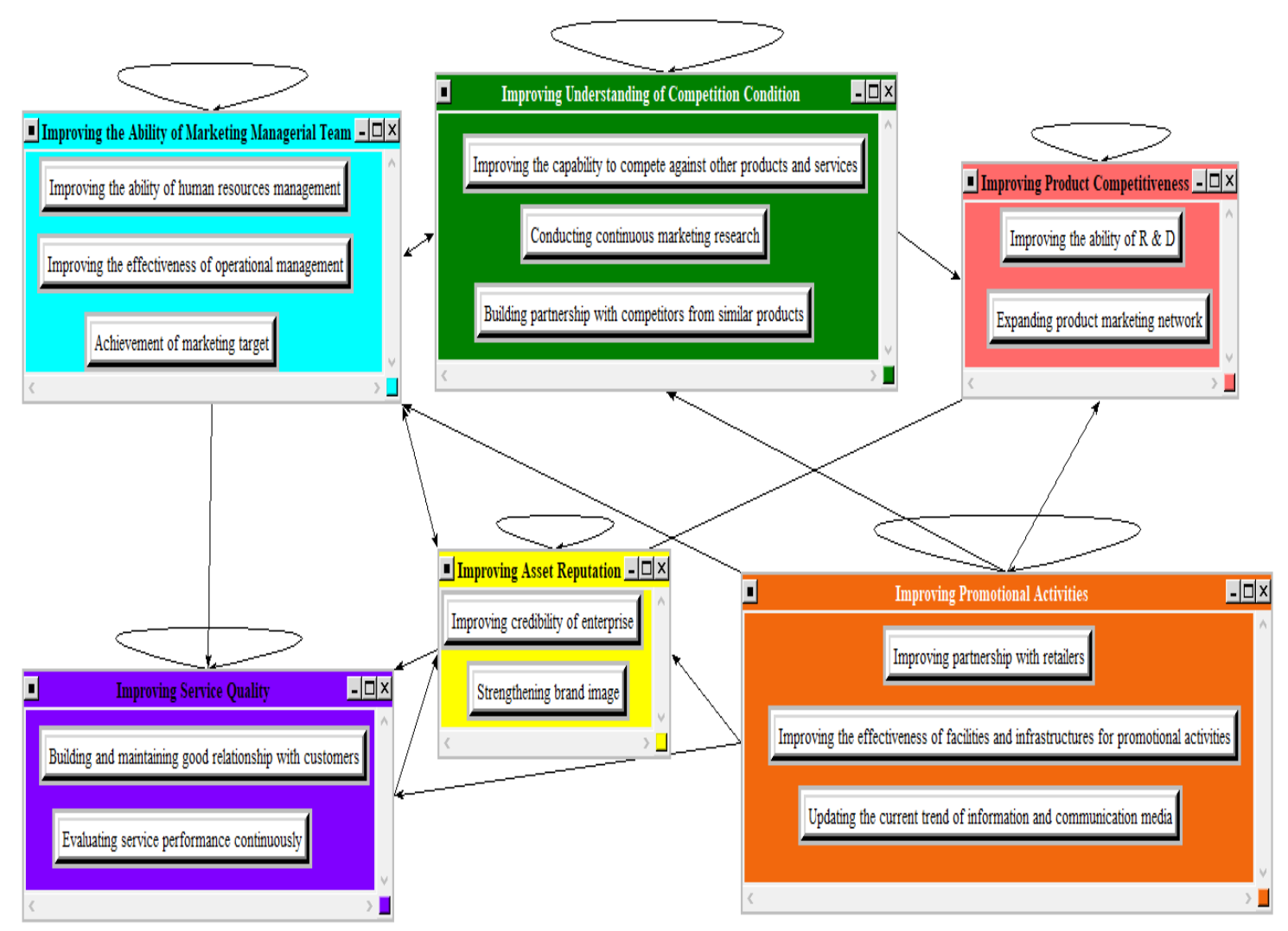

Figure 1 ANP model for structuring relationships between clusters

In ANP, there are two kinds of correlation: inner dependence and outer dependence. Inner dependence is a correlation between elements in the same cluster; this cluster will then relate to itself and make a loop. In this research, there was inner dependence in every criteria, therefore it 
could be established that each subcriterion and each criterion was connected. Outer dependence is a correlation between elements in different clusters; these clusters will then relate to the other clusters. For example, company managerial development increases asset reputation, which then increase promotion, and so on. The ANP model for structuring the relationships between clusters can be seen in Figure 1.

After analyzing the correlation of each alternative strategy obtained from ANP, weighting was conducted to determine the priority rate for each alternative strategy. Based on the weighting process, it was found that the highest market risk mitigation was the improvement in substrategy promotion, which increased the effectiveness of promotion facilities and infrastructure (0.296); complied with the development of information and communication media (0.292); and maintained service quality in the subcriterion of building and maintaining good relations with customers (0.105). The detailed strategy priority of risk mitigation can be seen in Table 4 .

Table 4 Priority results of market risk mitigation strategy for potato chip marketing

\begin{tabular}{|c|c|c|c|}
\hline Criterion & Subcriterion & Weight & Priority \\
\hline \multirow{3}{*}{$\begin{array}{l}\text { Improving the Ability of the } \\
\text { Marketing Managerial Team }\end{array}$} & $\begin{array}{l}\text { Improving the ability of human } \\
\text { resources management. }\end{array}$ & 0.070 & 4 \\
\hline & $\begin{array}{l}\text { Improving the effectiveness of } \\
\text { operational management. }\end{array}$ & 0.013 & 10 \\
\hline & Achievement of marketing targets. & 0.011 & 11 \\
\hline \multirow[t]{2}{*}{ Improving Services Quality } & $\begin{array}{l}\text { Building and maintaining good } \\
\text { relationships with customers. }\end{array}$ & 0.105 & 3 \\
\hline & $\begin{array}{l}\text { Evaluating service performance } \\
\text { continuously. }\end{array}$ & 0.049 & 6 \\
\hline \multirow{3}{*}{$\begin{array}{l}\text { Improving Promotional } \\
\text { Activities }\end{array}$} & Improving partnerships with retailers. & 0.036 & 7 \\
\hline & $\begin{array}{l}\text { Improving the effectiveness of facilities } \\
\text { and infrastructure for promotional } \\
\text { activities. }\end{array}$ & 0.296 & 1 \\
\hline & $\begin{array}{l}\text { Updating the current trends in } \\
\text { information and communication media. }\end{array}$ & 0.292 & 2 \\
\hline \multirow[t]{2}{*}{ Improving Asset Reputation } & $\begin{array}{l}\text { Improving the credibility of the } \\
\text { enterprise. }\end{array}$ & 0.007 & 12 \\
\hline & Strengthening brand image. & 0.052 & 5 \\
\hline \multirow{3}{*}{$\begin{array}{l}\text { Improving Understanding of } \\
\text { Competition Condition }\end{array}$} & $\begin{array}{l}\text { Improving the capability to compete } \\
\text { against other products and services. }\end{array}$ & 0.007 & 13 \\
\hline & $\begin{array}{l}\text { Conducting continuous marketing } \\
\text { research. }\end{array}$ & 0.023 & 9 \\
\hline & $\begin{array}{l}\text { Building partnerships with competitors } \\
\text { with similar products. }\end{array}$ & 0.005 & 14 \\
\hline \multirow{2}{*}{$\begin{array}{l}\text { Improving Product } \\
\text { Competitiveness }\end{array}$} & Improving the ability of R \& D. & 0.004 & 15 \\
\hline & $\begin{array}{l}\text { Expanding the product marketing } \\
\text { network. }\end{array}$ & 0.030 & 8 \\
\hline
\end{tabular}

These results indicate that the presence of infrastructure to support campaigns is a key strategy in mitigating the risk of marketing. This is in line with a number of previous research results (Samli \& Hook, 1995; Lowe, 2010), emphasizing the importance of the optimization of various media to enhance promotional activities. In fact, the research results of Kiumarsi et al. (2014) indicate that SMEs should create and focus on appropriate promotion and advertising strategies. The implementation of these strategies could improve the effectiveness of marketing, increasing sales, making the products more popular, and expanding the market area. 


\section{CONCLUSION}

Market risk assessment using fuzzy FMEA produces different results from conventional FMEA. They are more specific, and can therefore help to avoid the risks which are commonly encountered in marketing. The findings show that the most potential risks in potato chip marketing are promotion risk, caused by the inappropriateness of promotional activities; promotion targets; and the absence of a brand image. External factors are the competitiveness of similar products; the presence of substitute products; and new competitors. The third risk is product risk, which is related to the declining quality of the product and services, and the lack of innovation. This risk analysis was then considered as the basic formulation of risk mitigation strategy using the ANP method. Based on the weighting process, it was found that the highest market risk mitigation strategy lay in improvement in sub-strategy promotion to increase the effectiveness of promotion facilities and infrastructure (0.296); compliance with the development of information and communication media (0.292); and service quality maintenance in the subcriteria of building and maintaining good relationships with customers (0.105). The implementation of these strategies could improve marketing effectiveness, thereby increasing sales, making the products more popular, and expanding the market area.

\section{REFERENCES}

Abril, C., Rodriguez, C.B., 2016. Marketing Mix Effects on Private Labels Brand Equity. European Journal of Management and Bussiness Economics, Volume 25(30), pp. 168-175

Aghazadeh, H., 2015. Strategic Marketing Management: Achieving Superior Business Performance through Intelligent Marketing Strategy. Procedia - Social and Behavioral Sciences, Volume 207, pp. 125-134

Aminbakhsh, S., Gunduz, M., Sonmez, R., 2013. Safety Risk Assessment using Analytic Hierarchy Process (AHP) during Planning and Budgeting of Construction Projects. Journal of Safety Research, Volume 46, pp. 99-105

Anggadwita, G., Amani, H., Saragih, R., Alamanda, D.T., 2016. Competitive Strategy of Creative Application Content in the ASEAN Economic Community: Software Development using SWOT Analysis in Indonesia. International Journal of Economics and Management, Volume 10(S1), pp. 95-107

Astuti, R., Silalahi, R.L., Wijaya, G.D.P., 2015. Marketing Strategy based on Marketing Mix Influence on Purchasing Decisions of Malang Apples Consumers at Giant Olympic Garden Mall (MOG), Malang City, East Java Province, Indonesia. Agriculture and Agricultural Science Procedia, Volume 3, pp. 67-71

Berry, A., Rodriguez, E., Sandee, H., 2001. Small and Medium Enterprise Dynamics in Indonesia. Bulletin of Indonesian Economic Studies, Volume 37(3), pp. 363-384

Bao, T., Chang, T.S., 2014. Finding Disseminators via Electronic Word of Mouth Message for Effective Marketing Communications. Decision Support Systems, Volume 67, pp. 21-29

Bowles, J.B., Peláez, C.E., 1995. Fuzzy Logic Prioritization of Failures in a System Failure Mode, Effects and Criticality Analysis. Reliability Engineering \& System Safety, Volume 50(2), pp. 203-213

Brustbauer, J., 2016. Enterprise Risk Management in SMEs: Towards a Structural Model. International Small Business Journal: Researching Entrepreneurship, Volume 34(1), pp. 70-85

Cameron, I., Mannan, S., Németh, E., Park, S., Pasman, H., Rogers, W., Seligmann, B., 2017. Process Hazard Analysis, Hazard Identification and Scenario Definition: Are the Conventional Tools Sufficient, or Should and Can We Do Much Better? Process Safety and Environmental Protection, Volume 110, pp. 53-70 
Chaudary, A., Mohamed, M.H., 2017. Bayesian Monte Carlo and Maximum Likelihood Approach for Uncertainty Estimation and Risk Management: Application to Lake Oxygen Recovery M. Water Research, Volume 108, pp. 301-311

Cibinskienea, A., Snieskiene, G., 2015. Evaluation of City Tourism Competitiveness. Procedia - Social and Behavioral Sciences, Volume 213, pp. 105-110

Dagsuyu, C., Elifcan G., Mufide N., Ali K., 2016. Classical and Fuzzy FMEA Risk Analysis in a Sterilization Unit. Computers \& Industrial Engineering, Volume 101, pp. 286-294

Dawes, J., Nenycz-Thiel, M., 2013. Comparing Retailer Purchase Patterns and Brand Metrics for in-Store and Online Grocery Purchasing. Journal of Marketing Management, Volume 30(3-4), pp. 364-382

Dewi, D.S., Syairudin, B., Nikmah, E.N., 2015. Risk Management in New Product Development Process for Fashion Industry: Case Study in Hijab Industry. Procedia Manufacturing, Volume 4, pp. 383-391

Dhanani, A., 2008. The Management of Interest Rate Risk: Evidence from UK Companies. Journal of Applied Accounting Research, Volume 9(1), pp. 52-70

Eiser, J.R., Bostrom, A., Burton, I., Johnston, D.M., McClure, J., Paton, D., van der Pligt, J., White, M.P., 2012. Risk Interpretation and Action: A Conceptual Framework for Responses to Natural Hazards. International Journal of Disaster Risk Reduction, Volume 1, pp. 5-16

Falkner, E.M., Hiebl, M.R.W., 2015. Risk Management in SMEs: A Systematic Review of Available Evidence. The Journal of Risk Finance, Volume 16(2), pp. 122-144

Freixanet, J., 2012. Export Promotion Programs: Their Impact on Companies' Internationalization Performance and Competitiveness. International Bussiness Review, Volume 21(6), pp. 1065-1086

Ghandi, A., Lawell, C.-Y.C.L., 2017. On the Rate of Return and Risk Factors to International Oil Companies in Iran's Buy-Back Service Contracts. Energy Policy, Volume 103, pp. 1629

Haddoud, M.Y., Jones, P., Newbery, R., 2016. Export Promotion Programmes and SME's Performance. Journal of Small Bussiness and Enterprise Development, Volume 24(1), pp. $68-87$

Hasan, Z., Ali, N.Z., 2015. The Impact of Green Marketing Strategy on the Firm's Performance in Malaysia. Procedia - Social and Behavioral Sciences, Volume 172, pp. 463-470

He, Y.-X., Zhou, Y., Wang, B., Xiong, W., He, H.-Y., 2012. Early Warning Model for Risks of Energy Process and Energy Price Ratios in China's Energy Engineering. System Engineering Procedia. Volume 3, pp. 22-29

Henriques, I., Sadorsky, P., 2010. Can Environmental Sustainability be Used to Manage Energy Price Risk? Energy Economics. Volume 32(5), pp. 1131-1138

Kang, C.-C., Feng, C.-M., 2009. Risk Measurement and Risk Identification for BOT Projects: A Multi - Attribute Utility Approach. Mathematical and Computer Modelling, Volume 49 (9-10), pp. 1802-1815

Kiumarsi, S., Jayaraman, K., Isa, S.M., Varastegani, A., 2014. Marketing Strategies to Improve the Sales of Bakery Products of Small-Medium Enterprise (SMEs) in Malaysia. International Food Research Journal, Volume 21(6), pp. 2101-2107

Krasnikov, A., Jayachandran, S., 2008. The Relative Impact of Marketing, Research -andDevelopment, and Operations Capabilities on Firm Performance. Journal of Marketing, Volume 72(4), pp. 1-11

Kumar, S.N.A., 2012. A Study of Small Scale Industries: Marketing Strategies. Trans Asian Journal of Marketing \& Management Research, Volume 1(1), pp. 12-20

Kumru, M., Kumru, P.Y., 2013. Fuzzy FMEA Application to Improve Purchasing Process in A Public Hospital. Applied Soft Computing, Volume 13(1), pp. 721-733 
Lowe, B., 2010. Consumer Perceptions of Extra Free Product Promotions and Discounts: The Moderating Role of Perceived Performance Risk. Journal of Product and Brand Management, Volume 19(7), pp. 496-503

Nie, S., Li, Y.P., Liu, J., Huang, C.Z., 2016. Risk Management of Energy System for Identifying Optimal Power Mix with Financial-cost Minimization and Environmentalimpact Mitigation under Uncertainty. Energy Economics, Volume 61, pp. 313-329

Parsana, T.S., Patel, M.T., 2014. A Case Study: A Process FMEA Tool to Enhance Quality and Efficiency of Manufacturing Industry. Bonfring International Journal of Industrial Engineering and Management Science, Volume 4(3), pp. 145-152

Pauwels, K., Aksehirli, Z., Lackman, A., 2016. Like the Ad or the Brand? Marketing Stimulates Different Electronic Word-of-Mouth Content to Drive Online and Offline Performance. International Journal of Research in Marketing, Volume 33(3), pp. 639-655

Petrovic, D., Tanasijević, M., Milić, V., Lilic, N., Stojadinovic, S., Svrkota, I., 2014. Risk Assessment Model of Mining Equipment Failure based on Fuzzy Logic. Expert System with Applications, Volume 41(18), pp. 8157-8164

Rider, G., Dirk V.A., Carian V.D.S., Mason, J., Chen, X., 2009. Framework Model of Product Risk Assessment. International Journal of Injury Control and Safety Promotion, Volume 16(2), pp. 73-80

Rochman, N.T., Gumbira-Sa'id, E., Daryanto, A., Nuryartono, N., 2011. Analysis of Indonesian Agroindustry Competitiveness in Nanotechnology Development Perspective using SWOT-AHP Method. International Journal of Business and Management, Volume 6(8), pp. 235-244

Ryals, L.J., Knox, S., 2005. Measuring Risk-adjusted Customer Lifetime Value and Its Impact on Relationship Marketing Strategies and Shareholder Value. European Journal of Marketing, Volume 39(5/6), pp. 456-472

Saaty, T.L., 1996. Decision Making with Dependence and Feedback: The Analytic Network Process. RWS Publications, Pittsburgh

Samli, A.C., Hook Jr., R.C., 1995. Improving Marketing Education through Effective Promotion of Marketing Departments. Journal of Marketing for Higher Education. Volume 6(2), pp. 73-86

Santoso, I., Sa'adah, M., Wijana, S., 2017. QFD and Fuzzy AHP for Formulating Product Concept of Probiotic Beverages for Diabetic. Telkomnika, Volume 15(1), pp. 391-398

Segismundo, A., Miguel, P.A.C., 2008. Failure Mode and Effects Analysis (FMEA) in the Context of Risk Management in New Product Development: A Case Study in An Automotive Company. International Journal of Quality \& Reliability Management, Volume 25(9), pp. 899-912

Serpellaa, A.F. Ferradaa, X., Howarda, R., Rubio, L., 2014. Risk Management in Construction Projects: A Knowledge-based Approach. Procedia - Social and Behavioral Sciences, Volume 119, pp. 653-662

Silva, M.M., Gusmao, A.P.H.G., Poleto, T., Silva, L.C., Costa, A.P.C.S., 2014. A Multidimensional Approach to Information Security Risk Management using FMEA and Fuzzy Theory. International Journal of Information Management, Volume 34(6), pp. 733 740

Solomon, M.R., 2006. Chapter 1: An Introduction to Consumer Behaviour, in Prentice Hall Europe (Ed). Consumer Behaviour: A European perspective, $3^{\text {th }}$ Edition, Simon \& Schuster Company, Upper Saddle River, New Jersey, USA

Suryaningrat, I.B., 2016. Raw Material Procurement on Agroindustrial Supply Chain Management: A Case Survey of Fruit Processing Industries in Indonesia. Agriculture and Agriculture Sciences Procedia, Volume 9, pp. 253-257 
Tohidi, H., 2011. The Role of Risk Management in It Systems of Organizations. Procedia Computer Science, Volume 3, pp. 881-887

Vorhies, D.W., Morgan, R.E., Autry, C.W., 2009. Product-market Strategy and the Marketing Capabilities of the Firm: Impact on Market Effectiveness and Cash Flow Performance. Strategic Management Journal, Volume 30(12), pp. 1310-1334

Wang, Y.-M., Chin, K.-S., Poon, G.K.K., Yang, J.-B., 2009. Risk Evaluation in Failure Mode and Effect Analysis using Fuzzy Weighted Geometric Mean. Expert System with Application, 36(2), pp. 1195-1207

Wang, Y., 2016. What are the Biggest Obstacles to Growth of SME's in Developing Countries? A Picture Emerging from an Enterprise Survey. IES Working Paper 9/2016. IES FSV. Charles University

Weron, R., 2000. Energy Price Risk Management. Physica A: Statistical Mechanics, Volume 285(1-2), pp. 127-134

Yoo, B., Donthu, N., Lee, S., 2000. An examination of Selected Marketing Mix Elements and Brand Equity. Journal of the Academic of Marketing Science, Volume 28(195), pp. 195221 